\title{
Genetic Analysis of Vegetative-Stage Drought Tolerance in Cowpea
}

\author{
Alidu M. S. ${ }^{1 a}$, Atokple I. D. K. ${ }^{2 \star}$ and Akromah R. ${ }^{1 b}$
}

\author{
Crop Science Dept., Faculty of Agriculture, Kwame Nkrumah University of Science and \\ Technology, Private Mail Bag, Kumasi. \\ ${ }^{2}$ CSIR-Savannah Agricultural Research Institute, Tamale.
}

\section{ARTICLE INFO}

Article No.: 030613516

DOI: 10.15580/GJAS.2013.6.030613516

Submitted: 06/03/2013

Accepted: 22/06/2013

Published: 29/06/2013

${ }^{*}$ Corresponding Author

Atokple I. D. K.

E-mail: idkatokple@yahoo.com

Keywords:

Cowpea, Drought, Tolerance,

Combining Abilities, Heterosis,

Diallel Hybrids, Heritability, Trait

Correlation
The continued improvement in the yield of cowpea for the semi-arid regions where it is a dominant crop will record rapid progress if the genetic basis for yield under different moisture regimes is better understood. This study investigated the genetic combining abilities and heterosis for grain yield, yield components, flowering and biomass production among diallel hybrids derived from nine cowpea genotypes. Results showed that moisture stress significantly reduced grain yield, biomass production, and number of pods per plant. Only for grain yield was a significant interaction observed for moisture regimes. Genetic control for grain size, number of seeds per pod and days to flowering was dominated by additive genetic effects. For grain yield, both additive and non-additive genetic effects were dominant. The genetic control of yield under the two soil moisture conditions indicated that grain yield improvement will be more challenging for drought prone regions. Nonetheless, careful selection of genotypes that have complementary but different alleles for yield under different soil moisture conditions might permit yield improvement through recurrent selection. This study has identified parental lines, developed populations, and provided a breeding strategy for developing cowpea cultivars with higher grain yield for Guinea and Sudan savannah regions of West Africa. 


\section{INTRODUCTION}

Cowpea (Vigna unguiculata) [L.] Walp) is a source of livelihood to millions of relatively poor people in less developed countries of the tropics. It is one of the ancient grain legume crops cultivated in semi-arid West Africa where rainfall is characteristically low (mean annual range of 300-600 mm), variable in time and space and undependable (Fussell et al., 1991). The grain is valued for its high protein content of about $23-25 \%$ and $50-67 \%$ starch. The fresh young leaves, immature pods and peas are used as vegetables, while several snacks and main dishes are prepared from the grain. The haulms are used as fodder for livestock particularly during the dry season (Blade et al., 1997). Although cowpea contributes significantly to the income of farmers in the northern savannah zones of West Africa where varieties with grain yield potentials in excess of $3.0 \mathrm{t} / \mathrm{ha}$ have been developed for cultivation, farm level yields of cowpea are within the range of 0.3 to $0.65 \mathrm{t} / \mathrm{ha}$ (SARI, 1996 and 1997). Besides the problem of insect pests (Singh and Jackai, 1985), sensitivity to soil moisture stress during the various growth stages of the crop significantly reduces grain yield. The timing and intensity of drought in relation to the crop phenology, sensitivity of flower, pod and seed development to high night temperatures are important constraints to sustainable cowpea production. Though cowpea is reputed to be one of the most drought tolerant crops in semi-arid Africa, grain yield of the crop increases significantly where drought stress is minimal (Turk et al., 1980; Padi, 2004). The northern sector of Ghana produces the bulk of cowpea for Ghana and is gaining prominence in the hydromorphic lowlands between April to June preceding Rice, Maize and Sorghum production. After the cowpea is planted, drought incidence of between 20 and 30 days are not uncommon. Under this production system however, the variety of cowpea that is planted need to be particularly tolerant to drought during the vegetative phase.

Genotypic differences have been documented for different stages of phenological development of the crop, from emergence to pod maturity, in pigmentation and yield attributes (Fery and Singh, 1997). Identification and separation of varieties that tolerate unfavourable conditions such as drought would be of great value to farmers in the semi-arid zones including Northern Ghana.

These empirical approaches are slow, laborious and expensive because of the need to assess the yield of a large number of lines across several locations and years. Shakel et al., (1982) have argued that when selecting genotypes with increased drought resistance, it is reasonable to propose that the evaluation be made under irrigated conditions. Because of inconsistencies observed under water deficit conditions, they concluded that irrigated conditions might be a more reliable indicator of genotypic differences than measurements with plants under drought. Breeders typically use two strategies to improve drought tolerance. These include the exploitation of heterosis and direct selection for drought tolerance and its components (Abdelmula et al., 1999).

The study was therefore designed (1) to determine the genetics of grain and vegetative biomass yields under well-watered and drought stress conditions during the vegetative phase of cowpea, (2) establish the yield penalty associated with vegetativestage drought in cowpea in the parental lines and their $F_{1}$ hybrids, in relation to hybrid vigour for drought tolerance and (3) identify the cowpea genotype with the highest tolerance to vegetative-stage drought among a set of nine genotypes reputed for drought tolerance.

\section{MATERIALS AND METHODS}

\section{The cowpea genotypes}

Nine genotypes of cowpea were used for the study. Four of these genotypes, Omondaw, Apagbaala, Milo and Padi Tuya were obtained from CSIR - Savannah Agricultural Institute (CSIR-SARI) and used as female lines. These lines have been developed by SARI for general cultivation to increase productivity in the three Northern Regions of Ghana. The other five genotypes which were among the best drought-tolerant cowpea lines came from the International Institute of Tropical Agriculture (IITA) Kano, Nigeria. These lines included IT 93K-503-1, IT 89KD-374-57, IT 97K-499-35, IT 99K241-2 and IT 97K-568-19.

\section{Development of $F_{1}$ Seeds}

Seeds of the parental lines were planted in $32 \mathrm{~cm}$ diameter plastic pots filled with black, loamy top soil in the screen house at CSIR-SARI. At flowering, the female parents were each crossed with the same male parents to generate a total of $20 \mathrm{~F}_{1}$ populations in a Design II Mating Fashion (Table 1). Series of plantings of the parents were carried out between the period of June and December 2009 to synchronize flowering and undertake several crosses with the aim of obtaining a minimum of 150 seeds per cross. 
Table 1: Crossing scheme to generate $F_{1}$ seeds

\begin{tabular}{|c|c|c|c|c|c|}
\hline & \multicolumn{5}{|c|}{ Male Parents } \\
\hline $\begin{array}{c}\text { Female } \\
\text { Parents }\end{array}$ & IT 93K-503-1 & IT89KD-374-57 & IT97K-499-35 & IT 99K-241-2 & IT 97K-568-19 \\
\hline APAGBAALA & APA X 503 & APA X 374 & APA X 499 & APA X 241 & APA X 568 \\
\hline PADITUAYA & PADI X 503 & PADI X 374 & PADI X 499 & PADI X 241 & PADI X 568 \\
\hline OMUNDAW & OMUN X 503 & OMUN X 374 & OMUN X 499 & OMUN X 241 & OMUN X 568 \\
\hline MILO & MILO X 503 & MILO X 374 & MILO X 499 & MILO X 241 & MILO X 568 \\
\hline
\end{tabular}

\section{Field screening}

The field screening started in January 2010 under irrigation at CSIR-SARI Experimental Site, Golinga, $9^{\circ}$, $25^{\prime \prime} \mathrm{N}$ and $0^{\circ}, 58^{\prime \prime} \mathrm{W}$ within the Northern Guinea Savannah Zone. The zone is characterized by fairly uniform temperature distribution with a mean annual temperature of $28.3^{\circ} \mathrm{C}$. The relative humidity varies greatly - falling during the dry season and rising during the rainy season with an annual relative humidity of $54 \%$.

\section{Drought Stress Treatment}

Soil samples were taken from the two main plots (i.e. stressed and non-stressed plots) and the physical and chemical analyses carried in the laboratory for each replication. Additionally the soil moisture content before and after irrigation was also determined. After the characterization of the two plots, both the non stress and water stress experiments were irrigated to its water holding capacity and planted on the same day. For the water-stress experiment no further irrigation was done until after 30 days of planting. The non-stress experiment however received water based on the crop water demand established by daily field observations. After the 30 days had elapsed, both fields received water till pod maturity.

\section{Experimental design}

The experimental design was split-plot with watering regimes as main plots and test genotypes as sub-plots in three replications and completely randomised. For each plot, three rows of test plants were established at a spacing of $60 \times 20 \mathrm{~cm}$, one plant per stand. Each row contained five plants giving a total of 15 stands. On each side of the test plants, two rows of the cowpea variety, Marfo-Tuya were planted to serve as calibrator for drought intensity due to the natural variability in soil moisture content that was expected in the field. Additionally, 10-day intervals from the day of sowing, the soil moisture content in the water-stress plot were estimated using the Volumetric Method from the top $50 \mathrm{~cm}$.

\section{Statistical Analyses}

The data collected were analyzed using the GenStat Statistical Program (Discovery Edition 3.0). First, the data on each trait was separated into moisture stress or non-stress set and analysed, followed by analysis of variance using the North Carolina II Design. The ANOVA of this cross-classified experiment, involving $n_{1}$ males crossed to $n_{2}$ females and genotypes replicated $r$ times is illustrated in Table 2 below.

Table 2: General ANOVA of the North Carolina II Experiment

\begin{tabular}{llll}
\hline Source & Degree of freedom & Mean square & Expected mean square \\
\hline $\begin{array}{l}\text { Between male half-sib } \\
\text { family groups (M) }\end{array}$ & $n_{1}-1$ & $M S_{M}$ & $\sigma^{2}{ }_{w}+r \sigma^{2} M F+r n_{2} \sigma^{2} M$ \\
$\begin{array}{l}\text { Between female half-sib } \\
\text { family groups }(F)\end{array}$ & $n_{2}-1$ & $M S_{F}$ & $\sigma^{2}{ }_{w}+r \sigma^{2} M F+r n_{1} \sigma^{2} F$ \\
$M \times F$ & $\left(n_{1}-1\right)\left(n_{2}-1\right)$ & $M S_{F M}$ & $\sigma^{2}{ }^{2}+r \sigma_{M F}^{2}$ \\
Within full sib families & $n_{1} n_{2}(r-1)$ & $M S_{W}$ & $\sigma^{2}{ }^{2}$ \\
\hline
\end{tabular}


The assumptions underlying the design and analyses are:

I. No epitasis

II. No maternal effects

III. There is linkage equilibrium

IV. There is diploid inheritance

V. Random choice of both male and female parents

VI. Random allocation of progenies to experimental plots

VII. No replication for error

From the ANOVA, the additive $\left(\mathrm{V}_{\mathrm{A}}\right)$ and dominance $\left(\mathrm{V}_{\mathrm{D}}\right)$ variance components were estimated as follows:

$$
\begin{gathered}
\sigma_{\mathrm{w}}^{2}=\frac{1}{2} \mathrm{~V}_{\mathrm{A}}+\frac{3}{4} \mathrm{~V}_{\mathrm{D}}+\mathrm{V}_{\mathrm{I}} \\
V_{A}=\frac{1}{2}\left(4 \times \sigma_{\mathrm{M}}^{2}+4 \times \sigma_{\mathrm{F}}^{2}\right) \\
V_{D}=4 \times \sigma_{\mathrm{MF}}^{2}
\end{gathered}
$$

The data set for each trait was then arranged in a genotype $\mathrm{x}$ moisture stress regime and analyzed as a two-way ANOVA to determine differences between hybrids and their parents. The genotype factor included both parents and the $F_{1}$ progeny. Mid-parent heterosis $\left(\mathrm{H}_{\mathrm{mp}}\right)$ which describes the performance of crosses relative to the average performance of their parents was then estimated following Fonseca and Patterson

$$
\mathrm{H}_{\mathrm{mp}}=100 \times \frac{\mathrm{F} 1-\mathrm{MP}}{\mathrm{MP}}
$$

where $F 1=$ is the value of the hybrid for the particular set of parent $i$ and $j$; and $\mathrm{MP}=$ the mid parent value of parents $\mathrm{i}$ and $\mathrm{j}$.

The " $t$ " test was applied to determine whether $F_{1}$ hybrid means were statistically different from mid parent values (Wynne et al., 1970) as:

$\mathrm{t}_{\mathrm{ij}}=\mathrm{F} 1_{\mathrm{ij}}-\mathrm{MP} /(3 / 8 \mathrm{EMS}) 1 / 2$

Where: $\mathrm{EMS}=$ error mean square

Estimates of narrow sense heritability were obtained by regression of hybrid means over that of their respective mid-parental values. The relationship between traits was determined using the Pearson's correlation coefficient.

\section{Soil Characteristics}

Within the period of the stress, the volumetric water contents of the two fields showed marked differences, with the stressed field having consistently lower water content (Fig. 1).

\section{RESULTS}




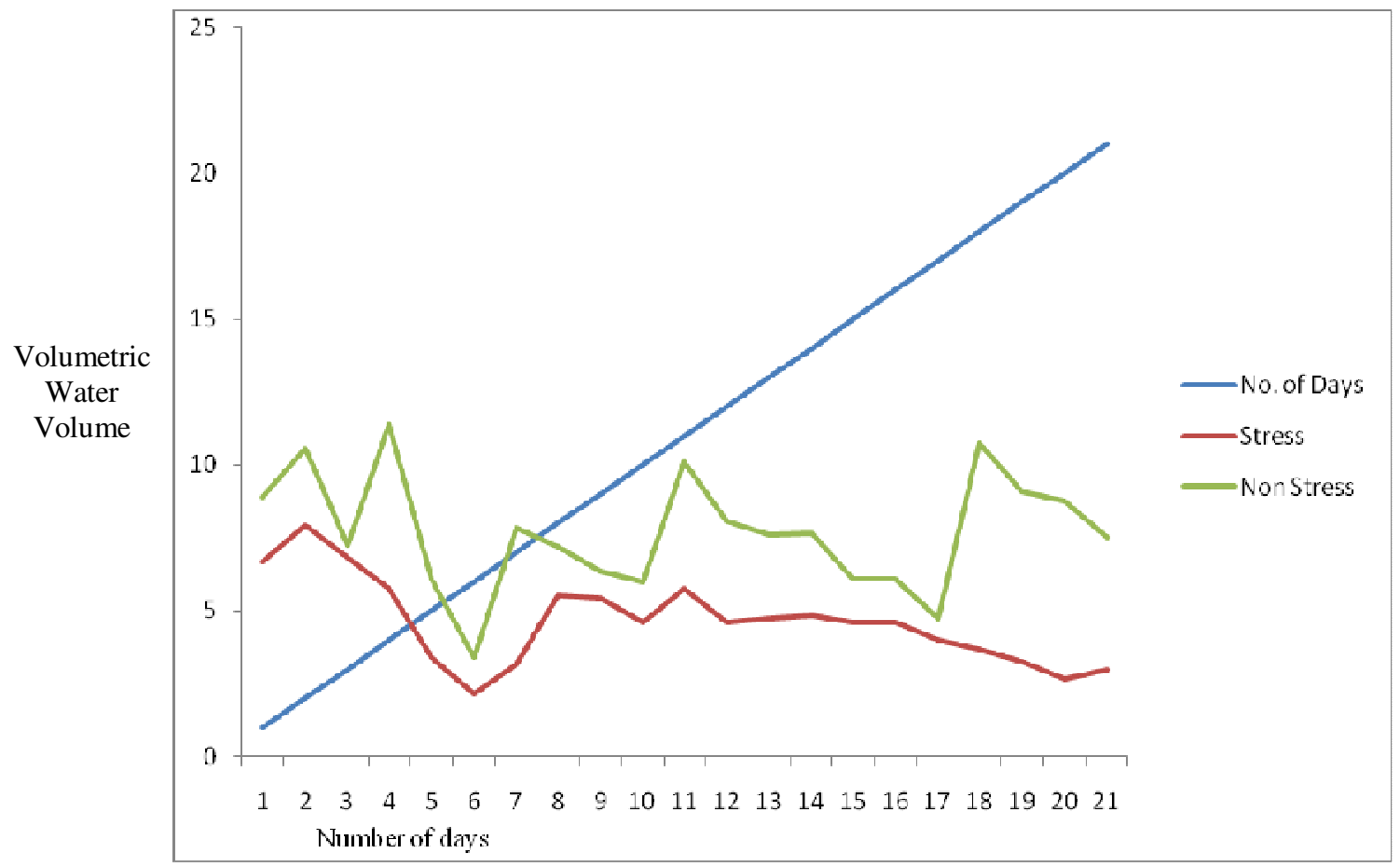

Figure 1: Volumetric water content of the stress and non stress plots

\section{General combining ability estimates}

The ANOVA following the North Carolina II design provided estimates of the General Combining Ability (GCA) for the five advanced breeding lines used as males and for the four cultivars used as females, and the Specific Combining Ability (SCA) for their crosses. In general, the GCA estimates for males were not significant $(P>0.05)$ for the majority of traits studied (Table 3). Only for biomass and days to flowering under non-stress condition and hundred seed weight were the GCA estimates for males significant. On the other hand, female GCA estimates were significant for all six traits studied under both stress and non- stress conditions (Table 3). For grain yield, Apagbaala and Padi Tuya contributed positively but their GCA estimates were significant only under adequate soil moisture conditions. The Milo cultivar was the best female under moisture stress conditions, contributing to increasing grain yield. Omondaw was the worst female as its GCA indicated that it reduced grain yield under both moisture regimes. The plot of observed grain yields over that predicted from parental G C A and overall mean showed that the $R^{2}$ value was far less than unity under adequate soil moisture (Figure 2) and under moisture stress (Figure 3 ) conditions. 


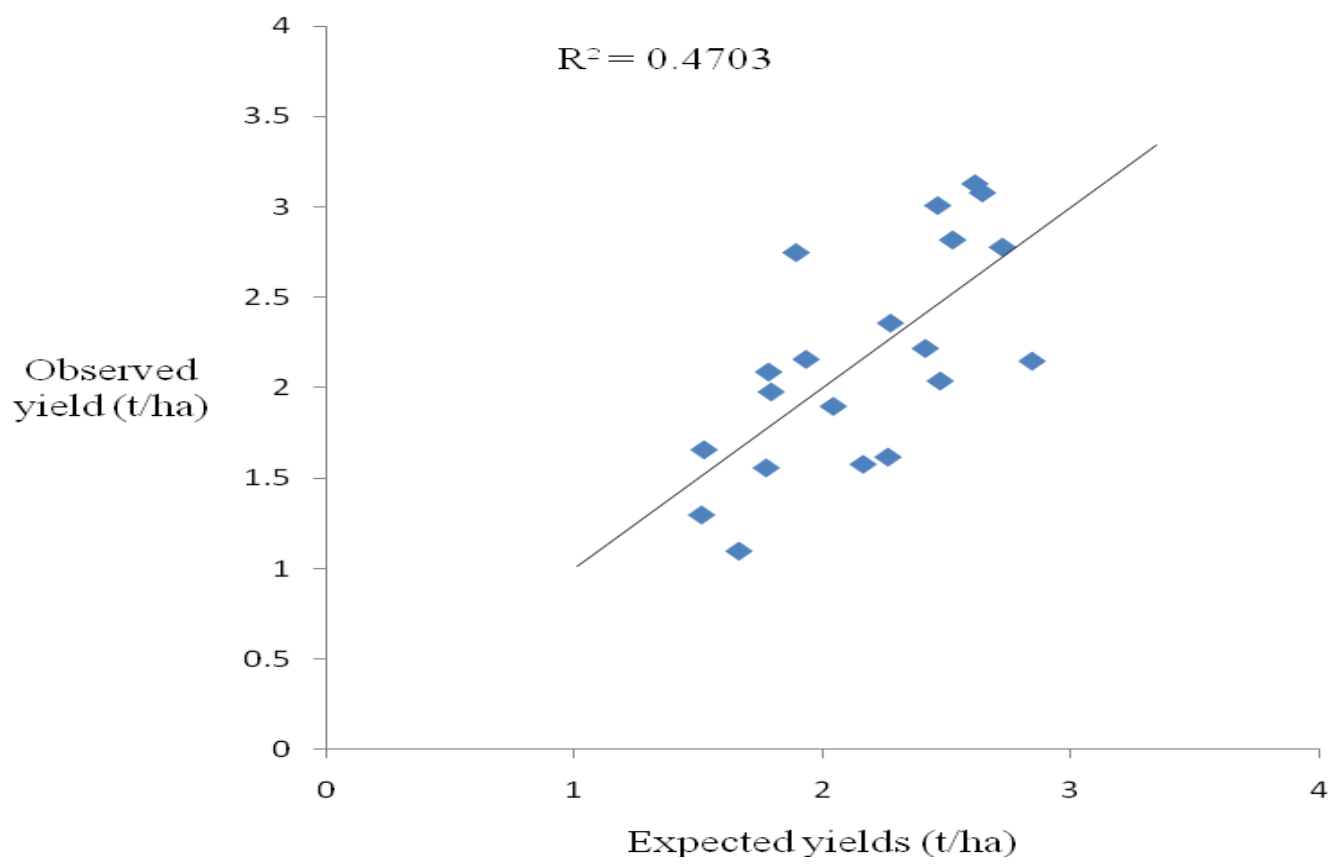

Figure 2: Observed grain yields under adequate soil moisture conditions of the 20 hybrids, and their predicted grain yields calculated for each cross from the GCA effect of two parents and the overall mean

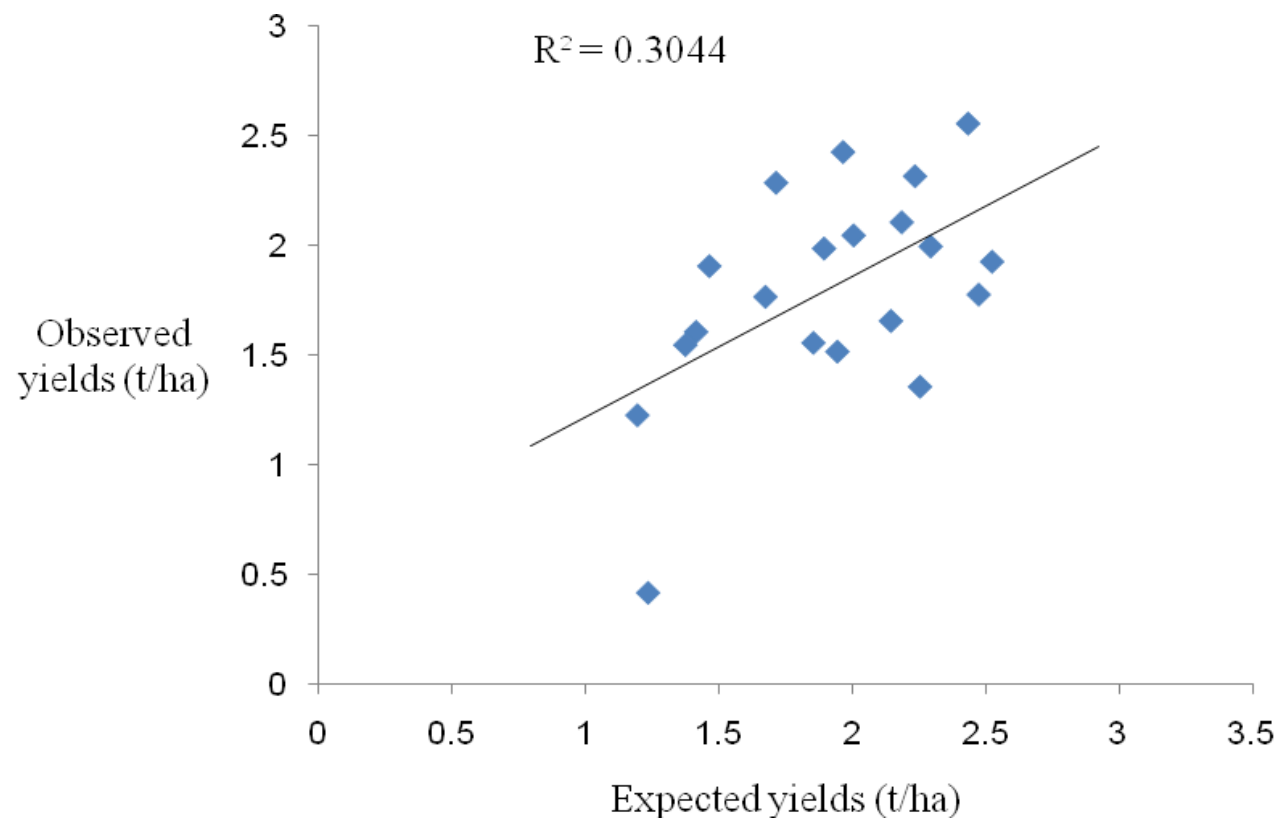

Figure 3: Observed grain yields under soil moisture stress conditions of the 20 hybrids, and their predicted grain yields calculated for each cross from the GCA effect of two parents and the overall mean

In addition to reducing grain yield, Omondaw performed poorly for all other traits studied. It contributed to increasing days to flowering (Table 5) and its GCA estimates for all other traits were negative, except for the number of seeds per pod under moisture stress where it produced a nonsignificant effect. On the other hand, except for the number of seeds per pod, Padi Tuya contributed favorably to all other traits studied. The contributions of 
Abagbaala and Milo to trait values were variable under both moisture regimes.

Among the five advanced breeding lines used as males, the significant GCA for biomass under no moisture stress was due to IT89KD-374-57 that contributed negatively, whereas for days to flower, the significant GCA was because IT97K-568-19

contributed to delay flowering (Table 3). For hundred seed weight, only IT99K-241-2 contributed to increasing seed size and caused a significant GCA effect

for males

(Table

6). 
Table 3: General combining abilities for grain yield, biomass and days to flowering of nine cowpea lines evaluated under contrasting moisture regimes during the vegetative phase

\begin{tabular}{|c|c|c|c|c|c|c|c|c|c|c|c|c|c|}
\hline & & \multicolumn{2}{|c|}{ Grain yield } & \multicolumn{2}{|c|}{ Biomass } & \multicolumn{2}{|c|}{ Days to flower } & \multicolumn{2}{|c|}{ Pods per plant } & \multicolumn{2}{|c|}{ Seeds per pod } & \multicolumn{2}{|c|}{$\begin{array}{c}\text { Hundred seed } \\
\text { wt }\end{array}$} \\
\hline & & $\begin{array}{c}\text { No } \\
\text { stress }\end{array}$ & Stress & $\begin{array}{c}\text { No } \\
\text { stress }\end{array}$ & Stress & $\begin{array}{l}\text { No } \\
\text { stress }\end{array}$ & Stress & $\begin{array}{l}\text { No } \\
\text { stress }\end{array}$ & Stress & $\begin{array}{l}\text { No } \\
\text { stress }\end{array}$ & Stress & $\begin{array}{l}\text { No } \\
\text { stress }\end{array}$ & Stress \\
\hline \multirow[t]{5}{*}{ Females } & Apagbaala & 0.26 & 0.16 & 0.24 & -0.57 & -1.72 & -2.03 & 3.1 & 1.73 & 0.00 & -0.68 & -1.03 & -0.47 \\
\hline & Milo & -0.22 & 0.311 & 0.17 & -0.02 & 1.48 & -0.17 & -0.9 & 1.14 & 0.78 & 0.92 & -2.16 & -3.24 \\
\hline & Omondaw & -0.49 & -0.46 & -0.99 & -0.22 & 2.08 & 2.50 & -2.3 & -3.82 & -0.41 & 0.12 & -1.20 & -0.60 \\
\hline & Padi Tuya & 0.46 & 0.02 & 0.58 & 0.81 & -1.85 & -0.30 & 0.1 & 0.95 & -0.36 & -0.35 & 4.39 & 4.30 \\
\hline & $\begin{array}{l}\text { Standard } \\
\text { error }\end{array}$ & 0.126 & 0.120 & 0.492 & 0.324 & 0.641 & 0.706 & 2.13 & 1.494 & 0.262 & 0.288 & 0.568 & 0.537 \\
\hline \multirow[t]{6}{*}{ Males } & $\begin{array}{l}\text { IT89KD- } \\
374-57\end{array}$ & 0.10 & -0.11 & -1.34 & -0.45 & -0.58 & -0.47 & -0.1 & -0.04 & -0.12 & -0.35 & -1.01 & 0.09 \\
\hline & $\begin{array}{l}\text { IT93K- } \\
503-1\end{array}$ & -0.01 & 0.12 & -0.37 & 0.00 & 0.25 & 0.20 & 1.8 & 2.44 & 0.09 & 0.07 & -.073 & -1.12 \\
\hline & $\begin{array}{l}\text { IT97K- } \\
499-35\end{array}$ & 0.22 & 0.03 & -0.34 & 0.72 & -0.67 & -1.38 & 0.1 & 1.77 & -0.19 & 0.48 & -0.45 & -0.61 \\
\hline & $\begin{array}{l}\text { IT97K- } \\
568-19\end{array}$ & -0.15 & -0.15 & 1.03 & -0.35 & 1.75 & 0.95 & 1.1 & -1.84 & 0.36 & 0.15 & 1.03 & -0.71 \\
\hline & $\begin{array}{l}\text { IT99K- } \\
241-2\end{array}$ & -0.16 & 0.07 & 1.03 & 0.10 & -0.75 & 0.70 & -2.9 & -2.41 & -0.14 & -0.35 & 1.16 & 2.36 \\
\hline & $\begin{array}{l}\text { Standard } \\
\text { error }\end{array}$ & Ns & Ns & 0.550 & Ns & 0.717 & Ns & Ns & Ns & ns & $n s$ & 0.535 & 0.600 \\
\hline
\end{tabular}




\section{Specific Combining Ability Estimates}

For grain yields, few SCA estimates were significantly different from zero $(P<0.05)$ under either moisture regimes. Under moisture stress, only Apagbaala $\times$ IT 97K- 499-35 and Padi Tuya $\times$ IT89KD-374-57 produced significant positive estimates (Table 7). Omondaw × IT 89KD-374-57 produced a significant negative SCA estimate for grain yield under moisture stress. Under no moisture stress conditions, only for Omondaw $\times$ IT 97K-499-35 was the SCA estimate for grain yield positive, and significantly different from zero (Table 5). SCA estimates for grain yield for Apagbaala $\times$ IT 99K-241-2, Milo $\times$ IT 97K-499-35, and Padi Tuya $\times$ IT 97K-499-35 were negative and significantly different from zero (Table 5).

Table 4: Specific combining ability estimates for grain yield in a diallel mating of nine cowpea genotypes under moisture stress during the vegetative phase

\begin{tabular}{llllll}
\hline Females & IT89KD-374-57 & IT93K-503-1 & IT97K-499-35 & IT97K-568-19 & IT99K-241-2 \\
\hline Apagbaala & 0.19 & -0.11 & 0.60 & -0.46 & -0.22 \\
Milo & 0.05 & 0.09 & -0.48 & 0.42 & -0.07 \\
Omondaw & -0.81 & 0.45 & 0.18 & -0.01 & 0.20 \\
Padi Tuya & 0.58 & -0.42 & -0.29 & 0.05 & 0.09 \\
\hline
\end{tabular}

Standard error: 0.269

Table 5: Specific combining ability estimates for grain yield in a diallel mating of nine cowpea genotypes under adequate soil moisture conditions

\begin{tabular}{llllll}
\hline Females & IT89KD-374-57 & IT93K-503-1 & IT97K- 499-35 & IT97K-568-19 & IT99K-241-2 \\
\hline Apagbaala & 0.30 & -0.19 & 0.44 & 0.09 & -0.64 \\
Milo & -0.14 & 0.23 & -0.59 & 0.19 & 0.31 \\
Omondaw & -0.21 & -0.57 & 0.85 & 0.14 & -0.22 \\
Padi Tuya & 0.06 & 0.52 & -0.70 & -0.43 & 0.55 \\
\hline
\end{tabular}

Standard error: 0.281

For the number of pods per plant, only SCA estimates under moisture stress was significant. Among these estimates, only for the cross Omondaw $\times$ IT 97K-49935 was the estimate positive and significantly different from zero (Table 9). Two other SCA estimates, Omondaw $\times$ IT 89KD-74-57 and Milo $\times$ IT 97K-499-35 were also significantly different from zero, but negative.

For the number of seeds per pod, weight of hundred seeds and days to $50 \%$ flowering, the ANOVA indicated non-significant SCA effects for all traits under both moisture regimes, and the various estimates are therefore presented.

Table 6: Specific combining ability estimates for number of pods per plant in a diallel mating of nine cowpea genotypes under moisture stress during the vegetative phase

\begin{tabular}{llllll}
\hline Females & IT89KD-374-57 & IT93K-503-1 & IT97K- 499-35 & IT97K-568-19 & IT99K-241-2 \\
\hline Apagbaala & 5.14 & -3.15 & 2.51 & -1.93 & -2.57 \\
Milo & 0.84 & 1.97 & -8.60 & 3.59 & 2.20 \\
Omondaw & -9.42 & -3.17 & 8.68 & 1.70 & 2.21 \\
Padi Tuya & 3.44 & 4.35 & -2.59 & -3.35 & -1.85 \\
\hline Standard error: 3.41 & & &
\end{tabular}

Under soil moisture stress the SCA estimate for biomass production was positive, and significant for only the cross Apagbaala $\times$ IT 89KD-74-57 (Table 10). Two other significant estimates for the SCA for biomass were recorded for Apagbaala $\times$ IT 99K-241-2 and Milo $\times$ IT 97K- 499-35, but these were negative estimates. Under adequate soil moisture conditions, two significant estimates were recorded for Milo $x$ IT97K-568-19 and Omondaw x IT 99K-241-2 (Table 11). Again, Milo $\times$ IT 97K- 499-35 recorded a significant negative estimate for biomass. 
Table 7: Specific combining ability estimates for biomass production in a diallel mating of nine cowpea genotypes under moisture stress during the vegetative phase

\begin{tabular}{llllll}
\hline & \multicolumn{5}{c}{ Males } \\
Females & IT89KD-374-57 & IT93K-503-1 & IT97K- 499-35 & IT97K-568-19 & IT99K-241-2 \\
\hline Apagbaala & 1.71 & -0.91 & 1.12 & -0.44 & -1.48 \\
Milo & 0.19 & 0.97 & -2.00 & 0.29 & 0.55 \\
Omondaw & -0.71 & -1.24 & 0.92 & -0.03 & 1.07 \\
Padi Tuya & -1.19 & 1.18 & -0.04 & 0.18 & -0.13 \\
\hline
\end{tabular}

Standard error: 0.724

Table 8: Specific combining ability estimates for biomass production in a diallel mating of nine cowpea genotypes under adequate soil moisture conditions

\begin{tabular}{llllll}
\hline & \multicolumn{5}{c}{ Males } \\
Females & IT89KD-374-57 & IT93K-503-1 & IT97K- 499-35 & IT97K-568-19 & IT99K-241-2 \\
\hline Apagbaala & 1.92 & -1.10 & 1.95 & -1.12 & -1.66 \\
Milo & 0.33 & -1.13 & -3.20 & 2.79 & 1.21 \\
Omondaw & -1.09 & -0.34 & -0.22 & -0.90 & 2.55 \\
Padi Tuya & -1.16 & 2.57 & 1.46 & -0.78 & -2.10 \\
\hline Standard arror: 1.100 & & & &
\end{tabular}

Standard error: 1.100

\section{Performance of parents and hybrids for various traits}

The results obtained from the ANOVA when the various datasets were analyzed as Genotype $(G) \times$ Moisture regime $(\mathrm{M})$ cross-classification showed an absence of $G \times M$ interaction for all six traits, except for grain yield. The main effect of moisture regime was not significant for days to flowering and number of seeds per pod. Moisture stress during the vegetative phase caused a significant reduction in biomass production, number of pods per plant, and grain yield (Table 9). Seed size as estimated by the weight of hundred seeds however increased under soil moisture stress.

Table 9: Main effects of moisture regime during the vegetative phase on the performance of cowpea parents and hybrids

\begin{tabular}{lllllll}
\hline $\begin{array}{l}\text { Moisture } \\
\text { regime }\end{array}$ & $\begin{array}{l}\text { Days to } \\
\text { flower }\end{array}$ & Biomass & $\begin{array}{l}\text { Pods per } \\
\text { plant }\end{array}$ & $\begin{array}{l}\text { Seeds per } \\
\text { pod }\end{array}$ & $\begin{array}{l}\text { Hundred } \\
\text { seed wt }\end{array}$ & Grain yield \\
\hline Stress & 59.4 & 6.43 & 18.2 & 11.1 & 19.7 & 1.73 \\
No Stress & 59.1 & 7.70 & 22.7 & 11.3 & 19.0 & 2.02 \\
SED & Ns & $\mathbf{0 . 3 9 1}$ & $\mathbf{1 . 1 9}$ & Ns & $\mathbf{0 . 3 1}$ & $\mathbf{0 . 0 6 5}$ \\
\hline
\end{tabular}

The main effect of genotypes was however significant for all six traits studied. As indicated by the ANOVA, the genotypes displayed sharp differences in their response to drought in terms of moisture stress. For the parents, Omondaw and Apagbaala were the most responsive to drought, losing up to $50 \%$ of their respective yields under adequate moisture when moisture stress was imposed during the vegetative phase (Table 13). The yield of Milo remained relatively unchanged, with an increase of $4.7 \%$ under moisture stress relative to adequate moisture conditions. Padi Tuya, IT 89KD-374-57, IT 99K-241-2 and IT 97K-56819 each gained a $20 \%$ yield advantage under moisture stress relative to adequate soil moisture conditions. IT 93K-503-1 recorded $11 \%$ yield advantage under moisture stress.

Among the progenies, grain yield under adequate soil moisture conditions ranged from 3.13 t/ha in Padi Tuya $\times$ IT 93K-503-1 to 1.10 t/ha for Omondaw $\times$ IT 93K-503-1. Interestingly, the top eight highest yielding hybrids under no moisture stress conditions were dominated by hybrids that have Padi Tuya or Apagbaala as female parents. Conversely, the least yielding hybrids generally involved Omondaw as female (Table 13). As with the parents, the genotypes that produced high yields under adequate moisture conditions had yield reductions due to stress. Poor yielding genotypes under adequate moisture stress tend to record yield advantages under moisture stress.

The number of days to $50 \%$ flowering among the parents differed by as much as 12 days, with IT 89KD-374-57 as the earliest to flower and IT 99K-2412 being the latest to flower (Table 13). The hybrid that flowered latest (Omondaw $\times$ IT 89KD-374-57) was however 5 days earlier than IT 99K-241-2. Surprisingly, Omondaw and IT 89KD-374-57 were the two parents with the earliest time to flower. The hybrids that had either Apagbaala or Padi Tuya as females were among the earliest to flower.

The total number of pods developed were higher in IT 97K-568-19, Milo and Omondaw, and least in IT 89KD-374-57 and IT 99K-241-2. Among the 
hybrids, the number of pods per plant ranged from 27 in Apagbaala $\times$ IT 89KD-374-57 and Padi Tuya $\times$ IT93K-503-1 to 8 in Omondaw $\times$ IT 89KD-374-57.

The parents with the highest number of seeds per pod were Milo, IT 97K-568-19 and Omondaw with an average of 13 seeds. Apagbaala and IT 89KD-37457 had the smallest number of 10 seeds per pod. The performance of the progeny fell within the range of that of the parents with the hybrid of the two parents, Apagbaala and IT 89KD-374-57 having the least number of 10 (Table 10). Among the hybrids, the five hybrids arising from Milo as the female recorded the highest number of 12 seeds per pod.

Table 10: Mean performance of nine cowpea genotypes and their F1 hybrids for various traits assessed under contrasting moisture regimes during the vegetative phase

\begin{tabular}{|c|c|c|c|c|c|c|c|}
\hline \multirow[b]{2}{*}{ Genotype } & \multicolumn{2}{|c|}{ Grain yield (t/ha) } & \multirow{2}{*}{$\begin{array}{l}\text { Days } \\
\text { to } \\
\text { flower }\end{array}$} & \multirow{2}{*}{$\begin{array}{l}\text { Biomas } \\
s(t / h a)\end{array}$} & \multirow{2}{*}{$\begin{array}{l}\text { Pods per } \\
\text { plant }\end{array}$} & \multirow{2}{*}{$\begin{array}{l}\text { Seeds } \\
\text { per pod }\end{array}$} & \multirow{2}{*}{$\begin{array}{l}\text { Hundred } \\
\text { seed wt } \\
(\mathrm{g})\end{array}$} \\
\hline & $\begin{array}{l}\text { No } \\
\text { Stress }\end{array}$ & Stress & & & & & \\
\hline Omondaw & 2.81 & 1.38 & 56.8 & 7.38 & 29.2 & 12.7 & 13.6 \\
\hline Milo & 2.33 & 2.44 & 58.7 & 8.40 & 30.0 & 13.3 & 13.0 \\
\hline Apagbaala & 1.92 & 0.95 & 58.7 & 4.41 & 22.7 & 9.7 & 15.9 \\
\hline IT97K-568-19 & 1.83 & 2.24 & 68.3 & 13.43 & 32.7 & 13.2 & 19.3 \\
\hline IT97K -499-35 & 1.68 & 1.34 & 60.7 & 5.18 & 23.2 & 11.5 & 16.9 \\
\hline IT93K-503-1 & 1.68 & 1.88 & 61.3 & 5.34 & 21.5 & 12.2 & 17.4 \\
\hline Padi Tuya & 1.36 & 1.65 & 58.3 & 7.36 & 18.7 & 9.8 & 27.1 \\
\hline IT89KD-374-57 & 0.90 & 1.08 & 55.7 & 4.20 & 13.7 & 9.7 & 17.7 \\
\hline IT99K-241-2 & 0.84 & 1.02 & 67.7 & 14.91 & 11.0 & 10.2 & 28.9 \\
\hline Padi Tuya $\times$ IT93K-503-1 & 3.13 & 1.52 & 56.8 & 9.09 & 7.1 & 11.3 & 22.0 \\
\hline Apagbaala $\times$ IT 97K-499-35 & 3.08 & 2.56 & 56.0 & 8.28 & 26.1 & 11.2 & 19.0 \\
\hline Padi Tuya $\times$ IT99k-241-2 & 3.01 & 1.99 & 57.2 & 6.85 & 16.3 & 10.2 & 26.6 \\
\hline Apagbaala $\times$ IT 89KD-374-57 & 2.82 & 2.00 & 55.2 & 7.46 & 27.4 & 9.7 & 19.3 \\
\hline Padi Tuya $\times$ IT 89KD-374-57 & 2.78 & 2.29 & 56.8 & 5.33 & 22.6 & 10.4 & 23.9 \\
\hline Omondaw × IT 97K-499-35 & 2.75 & 1.55 & 58.3 & 6.64 & 25.1 & 11.2 & 18.0 \\
\hline Apagbaala $\times$ IT97K-568-19 & 2.36 & 1.36 & 58.8 & 6.11 & 18.8 & 11.5 & 17.7 \\
\hline Apagbaala $\times$ IT93K-503-1 & 2.22 & 1.93 & 56.7 & 5.36 & 22.0 & 11.1 & 18.1 \\
\hline Milo × IT93K-503-1 & 2.16 & 2.32 & 59.8 & 6.51 & 22.3 & 12.3 & 16.0 \\
\hline Padi Tuya × IT 97K-499-35 & 2.15 & 1.56 & 57.2 & 8.30 & 18.0 & 10.9 & 22.6 \\
\hline Milo $\times$ IT99k-241-2 & 2.09 & 2.11 & 60.0 & 8.23 & 20.7 & 11.6 & 18.9 \\
\hline Padi Tuya × IT97K-568-19 & 2.04 & 1.77 & 59.7 & 7.44 & 16.4 & 11.2 & 24.1 \\
\hline Milo $\times$ IT97K-568-19 & 1.98 & 2.43 & 59.8 & 8.66 & 22.7 & 12.2 & 17.8 \\
\hline Milo $\times$ IT 89KD-374-57 & 1.90 & 2.05 & 57.8 & 6.15 & 20.0 & 12.0 & 15.2 \\
\hline Omondaw $\times$ IT97K-568-19 & 1.66 & 1.23 & 61.5 & 5.97 & 18.7 & 10.8 & 19.1 \\
\hline
\end{tabular}




\begin{tabular}{llllllll} 
Apagbaala $\times$ IT99k-241-2 & 1.62 & 1.78 & 57.0 & 5.54 & 15.6 & 10.5 & 19.8 \\
Milo $\times$ IT 97K-499-35 & 1.58 & 1.66 & 58.8 & 4.38 & 12.8 & 11.8 & 16.3 \\
Omondaw $\times$ IT 89KD-374-57 & 1.56 & 0.42 & 62.5 & 4.30 & 8.4 & 11.5 & 17.9 \\
Omondaw $\times$ IT99k-241-2 & 1.30 & 1.61 & 60.2 & 8.47 & 14.9 & 11.3 & 19.8 \\
Omondaw $\times$ IT93K-503-1 & 1.10 & 1.91 & 62.0 & 5.12 & 15.2 & 10.2 & 18.2 \\
SED (P< $\mathbf{0 . 0 5})$ & 0.397 & 0.381 & 1.43 & 1.507 & 4.51 & 0.63 & 1.18 \\
\hline
\end{tabular}

For the parents, seed size as estimated by the weight of hundred seeds was larger in IT 99K-241-2 and Padi Tuya recording 28.9 and $27.1 \mathrm{~g}$, respectively. Omondaw and Milo were the parents with the smallest size seeds. The performance of the hybrids for seed size could be predicted adequately from that of their parents. Padi Tuya $\times$ IT 99K-241-2 had the largest seed size, with the next best four all having Padi Tuya as the female parent.

\section{MidParent Heterosis}

Superiority of the hybrids over the mid parental values was determined for each of the six traits using means across moisture regimes for traits where a significant interaction was not observed. Significant genotype $x$ moisture regime effect was observed for grain yield so estimates for heterosis were computed separately.

Under both stress and adequate soil moisture conditions, heterosis for grain yield was recorded for five hybrids including Apagbaala $\times$ IT 97K-499-35, Apagbaala $\times$ IT 89KD-374-57, Apagbaala $\times$ IT 99K241-2, Padi Tuya $\times$ IT 89KD-374-57 and Padi Tuya $\times$ IT 99K-241-2 (Table 11). Among these, the hybrids that have Abagbaala as the female parent had favourable heterosis for most traits. Conversely, hybrids with Omondaw as the female parent generally recorded unfavourable heterosis for the majority of traits.

Table 11: Estimates of Mid-parent heterosis of $F_{1}$ hybrids of nine cowpea genotypes for various traits assessed under contrasting moisture regimes during vegetative phase

\begin{tabular}{|c|c|c|c|c|c|c|c|}
\hline \multirow[t]{2}{*}{ Genotype } & \multirow{2}{*}{$\begin{array}{l}\text { Days to } \\
\text { flower }\end{array}$} & \multirow[t]{2}{*}{ Biomass } & \multirow{2}{*}{$\begin{array}{l}\text { Pods } \\
\text { per } \\
\text { plant }\end{array}$} & \multirow{2}{*}{$\begin{array}{l}\text { Seeds } \\
\text { per pod }\end{array}$} & \multirow{2}{*}{$\begin{array}{l}\text { Hundred } \\
\text { seed wt }\end{array}$} & \multicolumn{2}{|c|}{ Grain yield } \\
\hline & & & & & & Stress & $\begin{array}{c}\text { No } \\
\text { stress }\end{array}$ \\
\hline Apagbaala $\times$ IT 97K-499-35 & $-6.20^{*}$ & $72.68^{*}$ & 13.73 & 5.66 & $15.85^{\star}$ & $123.58^{*}$ & $71.11^{*}$ \\
\hline Apagbaala $\times$ IT 89KD-374-57 & -3.50 & 73.29 & 50.55 & 0.00 & $14.88^{*}$ & $97.04^{*}$ & $100.00^{*}$ \\
\hline Apagbaala $\times$ IT93K-503-1 & $-5.50^{*}$ & 9.95 & -0.45 & 1.37 & 8.71 & 36.40 & 23.33 \\
\hline Apagbaala $\times$ IT97K-568-19 & $-7.40^{*}$ & -31.50 & -32.13 & 0.44 & 0.57 & -14.73 & 25.87 \\
\hline Apagbaala $\times$ IT99k-241-2 & $-9.81^{*}$ & $-42.65^{\star}$ & -7.42 & 5.53 & $-11.61^{*}$ & $80.71^{*}$ & 17.39 \\
\hline Padi Tuya $\times$ IT 97K-499-35 & 0.09 & 6.14 & -19.64 & 3.81 & -1.95 & -25.89 & $-3.15^{*}$ \\
\hline Padi Tuya × IT 89KD-374-57 & -0.35 & -7.79 & 39.51 & 6.67 & 6.70 & $67.77^{*}$ & $146.02^{*}$ \\
\hline Padi Tuya $\times$ IT93K-503-1 & -5.02 & 43.15 & 34.83 & 2.73 & -1.12 & -13.88 & $105.92^{*}$ \\
\hline Padi Tuya × IT97K-568-19 & $-5.69^{*}$ & -28.43 & -36.19 & -2.61 & 3.88 & -9.00 & 27.90 \\
\hline Padi Tuya $\times$ IT99k-241-2 & $-9.21^{*}$ & $-38.48^{*}$ & 9.76 & 2.00 & -5.00 & $49.06^{*}$ & $173.64^{*}$ \\
\hline Omondaw × IT 97K-499-35 & -0.77 & 5.73 & -4.20 & -7.44 & $18.03^{*}$ & 13.97 & 22.49 \\
\hline Omondaw $\times$ IT 89KD-374-57 & $11.11^{*}$ & -25.73 & $-61.03^{*}$ & 2.68 & 14.38 & $-65.85^{*}$ & -15.90 \\
\hline Omondaw $\times$ IT93K-503-1 & 5.00 & -19.50 & $-40.04^{*}$ & $-18.07^{\star}$ & $17.42^{*}$ & 17.18 & $-51.00^{*}$ \\
\hline Omondaw x IT97K-568-19 & -1.68 & $-42.62^{*}$ & $-39.58^{*}$ & $-16.60^{\star}$ & $16.11^{*}$ & $-32.04^{*}$ & $-28.45^{*}$ \\
\hline
\end{tabular}




\begin{tabular}{lccccccc} 
Omondaw × IT99k-241-2 & -3.29 & -24.00 & -25.87 & -1.31 & -6.82 & 34.17 & -28.77 \\
Milo $\times$ IT 97K-499-35 & -1.51 & -35.49 & $-51.88^{*}$ & -4.84 & 9.03 & -12.17 & -21.20 \\
Milo $\times$ IT 89KD-374-57 & 1.05 & -2.38 & -8.47 & 4.35 & -0.98 & 16.48 & 17.65 \\
Milo $\times$ IT93K-503-1 & -0.33 & -5.24 & -13.40 & -3.53 & 5.26 & 7.41 & 7.73 \\
Milo $\times$ IT97K-568-19 & $-5.83^{*}$ & -20.66 & -27.59 & -7.92 & 10.22 & 3.85 & -4.81 \\
Milo $\times$ IT99k-241-2 & $-5.06^{*}$ & $-29.39^{*}$ & 0.98 & -1.28 & -9.79 & 21.97 & 31.86 \\
\hline
\end{tabular}

*Significant at $P<0.05$

\section{Variance components}

The additive and dominance variance components were estimated for each trait under stress or adequate soil moisture conditions (Table 12). Days to flowering, weight of hundred seeds and number of seeds per pod were conditioned mainly by additive genes. For biomass production, number of pods per plant and grain yield, dominance variance was higher than the additive variance

Table 12: Additive $\left(\mathrm{V}_{\mathrm{A}}\right)$ and dominance $\left(\mathrm{V}_{\mathrm{D}}\right)$ variance components from a diallel mating of cowpea genotypes evaluated under contrasting moisture regimes during the dry

\begin{tabular}{lllll} 
& \multicolumn{3}{c}{ season } & \\
& $\begin{array}{l}\text { Stress } \\
\mathrm{V}_{\mathrm{A}}\end{array}$ & $\mathrm{V}_{\mathrm{D}}$ & $\begin{array}{l}\text { No stress } \\
\mathrm{V}_{\mathrm{A}}\end{array}$ & $\mathrm{V}_{\mathrm{D}}$ \\
\hline Biomass & 0.028 & 4.440 & 0.00 & 14.284 \\
Days to flower & 7.242 & 0.00 & 9.112 & 0.00 \\
Hundred seed weight & 22.806 & 0.00 & 18.288 & 0.00 \\
Pods per plant & 0.420 & 83.12 & 0.00 & 23.4 \\
Seeds per pod & 0.756 & 0.080 & 0.436 & 0.240 \\
Yield & 0.128 & 0.588 & 0.255 & 0.908 \\
\hline
\end{tabular}

\section{Heritability estimates}

Estimates of narrow sense heritability were obtained by regression of hybrid means over that of their respective mid-parental values. Heritability estimate was high for the hundred seed weight, and moderate for number of seeds per pod (Table 13). Estimates of heritability were low for yield under both drought and adequate moisture conditions, as well as for biomass production. For the number of pods per plant, a very low value of 0.01 was obtained.

Table 13: Narrow sense heritability estimates of agronomic traits estimated by parent offspring regression of cowpea hybrids evaluated under contrasting moisture regimes

\section{Trait}

Days to flower

Biomass

Pods per plant

Seeds per pod

Hundred seed weight

Grain yield (moisture stress)

Grain yield (no moisture stress)
Narrow sense heritability

0.14

0.17

0.01

0.41

0.71

0.25 


\section{Trait correlations}

Pearson's correlation coefficient was determined between the six traits recorded in the experiment (Table 14). Most significant were between yield components, or between yield components and yield.
Late flowering genotypes were associated with high biomass yields with $r=0.547$. Under adequate soil moisture conditions, genotypes that were late to flower produced lower grain yields. Under moisture stress however, this relationship was not statistically significant.

Table 14: Simple correlation coefficients between agronomic traits of nine cowpea line and their $F_{1}$ hybrids

\begin{tabular}{|c|c|c|c|c|c|c|c|}
\hline & $\begin{array}{l}\text { Biom } \\
\text { ass }\end{array}$ & $\begin{array}{l}\text { Days to } \\
\text { Flower }\end{array}$ & $\begin{array}{l}\text { Hundred } \\
\text { seed wt }\end{array}$ & Pods/plant & $\begin{array}{l}\text { Seeds } \\
\text { per pod }\end{array}$ & $\begin{array}{l}\text { Yield } \\
\text { (no stress) }\end{array}$ & $\begin{array}{l}\text { Yield } \\
\text { (stress) }\end{array}$ \\
\hline Biomass & - & $0.547^{* \star}$ & $0.421^{*}$ & 0.264 & 0.235 & 0.114 & 0.206 \\
\hline Days to Flower & & - & 0.167 & -0.147 & 0.280 & $-0.531^{* *}$ & -0.181 \\
\hline Hundred seed wt & & & - & -0.355 & $-0.548^{\star *}$ & -0.067 & -0.078 \\
\hline Pods/plant & & & & - & $0.457^{*}$ & $0.626^{* *}$ & $0.525^{\star}$ \\
\hline Seeds/pod & & & & & - & 0.179 & 0.356 \\
\hline $\begin{array}{l}\text { Yield } \\
\text { (no stress) }\end{array}$ & & & & & & - & $0.408^{*}$ \\
\hline
\end{tabular}

${ }^{*}$ Significant at $P<0.05 ;{ }^{*}$ Significant at $P<0.01$

\section{DISCUSSIONS}

Although cowpea is reputed as one of the most drought tolerant crops in semi-arid Africa (Ehlers and Hall, 1997), significant differences exist among cowpea genotypes for drought tolerance at various growth stages (Mai-Kodomi et al., 1999; Watanabe et al., 1997). In the present study that evaluated nine cowpea genotypes and 20 hybrids derived from them, considerable variability in tolerance to drought imposed during the vegetative stage was observed. The significant genotype $\mathrm{x}$ moisture regime interaction effect on grain yield that caused re-ranking of genotypes for yield superiority attests to the wide differences in response to drought among the genotypes tested. The parental lines were selected to represent a diverse array of the available germplasm to include landrace-type cultivars, improved cultivars and advanced breeding lines. This variability was reflected in having significant genotype effects for all six traits for which they were assessed. Although the grain yields reported in the present study were much higher than is typical for West Africa, yields of a similar magnitude were reported at IITA, Kano in Nigeria (DingKuhn et al., 2006).

The mating design most often employed in the assessment of combining ability is the diallel (Griffing 1956; Gardner and Eberhart 1966). This allows the selection of superior pure lines for hybridization based on type of gene action. The General Combining Ability (GCA) which captures only the additive portion of the genetic variance was preponderant for days to flowering, hundred seed weight, and the number of seeds per pod. As additive genetic variance is the variance of breeding values and the main determinant of response to selection (Falconer, 1996), these traits will be easy to improve by simple selection procedures such as mass selection. Attesting to their simple inheritance, these traits have been shown to have high heritabilities under different

cropping systems (Padi and Ehlers, 2008; Padi 2007). In the present study, moderate to high heritabilities were obtained for these traits, except for the number of days to flowering. The low estimate of heritability for days to flowering based on parent-hybrid regression is not surprising. The dominance of earliness to flower over lateness to flower in cowpea is well known but with few genes underlying this trait selection should be effective in the early generations (Padi, 2008). Among these traits, the hundred seed weight (a measure of grain size) is the most important to consumers, directly influencing the market value of cowpea grains in West Africa ((Langyintuo et al., 2003). In the present study, Padi Tuya and IT 97K-241-2 showed the largest seed sizes and the best GCA for grain size. Selections from populations derived from a cross between these parents have the best potential for increasing seed size for consumers.

Based on observations on stem greenness, unifoliate senescence, wilting, trifoliate abscission, and anthocyanin accumulation made on cowpea genotypes that were subjected to moisture stress for 30 days during the vegetative phase, Muchero et al., (2008) classified IT 93K-503-1 as highly tolerant to drought. In that study, IT 97K-499-39, a sister line of IT 97K-49935 used in the present study was considered tolerant to drought. Subsequently, Muchero et al., (2008) used recombinant inbred lines developed with IT 93K-503-1 as one of the parents to map QTLs for drought tolerance. The performance of IT 93K-503-1 in the present study affirms its tolerance to vegetative-stage drought as it recorded a $5 \%$ increase in yield under moisture stress. Relative to its performance, however, genotypes with better tolerance to drought were included in the present study. Lines with potential for developing drought tolerant genotypes are Milo and IT 97K-568-19. 
Jatasra (1980) showed that additive gene action governs inheritance of grain yield in cowpea. In the present study, however, both non-additive and additive gene action were evident, though the nonadditive gene action was more dominant. The $r^{2}$ value obtained from the regression of observed yields over expected yields decreased from 0.47 under adequate soil moisture conditions to 0.30 under soil moisture stress indicating that improving cowpea yield will be more challenging for moisture stress conditions. Where both additive and non-additive variance components are important for a trait, it is not always easy to predict hybrid performance from parental performance. In the present study, Padi Tuya combined well for yield under adequate soil moisture conditions, but not for stress conditions. On the other hand, Milo combined well for yield under stress conditions rather than under adequate soil moisture conditions. A recurrent selection program that makes use of favourable alleles from different genetic backgrounds might help develop cultivars with increased yield under both adequate and moisture stress conditions.

Hall et al., (1997) and Singh et al., (1997) have argued that early maturing varieties depend more on drought escape mechanisms, which enable them to complete their life cycle before the occurrence of terminal drought. If, however, they are exposed to intermittent moisture stress during the vegetative or reproductive stages, they perform very poorly. The observations made in the present study are contrary to these earlier observations since a negative correlation was observed between days to flowering and grain yield. In the present study a moderate correlation coefficient was observed between yield under stress and optimal moisture conditions. Bänziger et al., (1997) reported that the genetic correlation between yield in stress and optimal environments tends to decrease as stress intensity increases. Consistent with the moderate correlation between yield in stress and non-stress soil conditions, interactions between GCA and soil moisture conditions for yield were evident from the relative values of parental GCA. This suggests that selection in an optimal environment is unlikely to be the most effective way of identifying superior genotypes for stress environments. This observations is made obvious by the behaviour of hybrids obtained from Milo (suitable for drought conditions) and from Padi Tuya (suitable for adequate moisture conditions).

Hybrids make maximum use of heterosis by combining favorable alleles of the individual homozygous parents. Falconer and Mackay 1996 noted that heterosis can only occur when parental cultivars used for $F_{1}$ production differ in gene frequencies. In the present study, the heterotic response was maximized largely because (i) the $F_{1}$ seeds were done carefully by hand pollination to ensure $100 \%$ purity; (ii) the parental divergence was high as the parents originated from diverse geographical regions. The four females used were selected to represent a wide array of backgrounds such as landrace, improved cultivars and adapted exotic introduction. All males used were of exotic background.
This study demonstrated that the development of high yielding hybrids, which equal or exceed the performance of elite commercial cultivars, is possible by crossing between high-yielding cowpea germplasm. The contributions of both GCA and SCA were important in explaining variation in grain yield among these hybrids. Even though the magnitude of GCA effects was less than that for SCA, under each moisture regime, the highest-yielding crosses involved at least one parent that possessed significant positive GCA effects for yield under that particular moisture condition. These results clearly indicate that yield can be improved by exploiting additive gene effects through such selection schemes as recurrent selection using genotypes that possess different responses to drought, and with high GCA effects to capitalize on favourable additive variation.

The high values of mid-parent heterosis was expected because the requisite causes of heterosis, viz., directional dominance and divergent allele frequencies, were likely to occur from the planned selection of local cultivars as females and exotic germplasm as males. Currently, however, cowpea is not grown as a hybrid crop. In self-pollinated plant species, it is rather easy to produce hybrid seed if male sterile lines are available and can be used as the female parent. It may be possible for chemical induction of male sterility in cowpea. There are at least four classes of chemical agents, including plant-growth regulators and substances that disrupt floral development, metabolic inhibitors, inhibitors of microspore development, and inhibitors of pollen fertility. Since the hybrid seeds must be harvested from the female parent only, the magnitude of heterosis should be sufficiently high to compensate for the cost of producing hybrid seeds in self-pollinating crops. The current results show that significance of heterosis obtained from diverse cowpea genotypes was sizable and worth exploring further.

Development of improved cultivars with increasingly shorter duration enables Upland Rice, Maize and Sorghum to be grown after a crop of Cowpea is harvested. This permits increased useefficiency of land in the single rainy season that characterizes the Guinea and Sudan savannah ecologies. The strong negative correlation observed between grain yield and days to flowering, coupled with the strong influence of additive gene action for days to flowering will permit the development of Cowpea cultivars suitable to pre-cereal cultivation systems in Northern Ghana.

The present study has shown that additive gene effects contribute to yield variation in Cowpea. With the relatively small effects of additive variance obtained for yield, recombinant inbred lines should be developed from crosses of lines that showed favourable GCA for yield. In particular crosses obtained from Padi Tuya, Milo and Apagbaala should be developed to the $F_{5}$ generation in large numbers per population. These lines should be screened in replicated plots after selections for simply inherited traits as seed size, days to flowering and number of seeds per pod are made on individual plants. 
It is important however that in developing cultivars from these populations, adequate attention is given to seed coat colour as the $F_{2}$ seeds obtained showed a number of undesirable seed coat characteristics. Segregation for seed colour that will occur in later generations will offer the opportunity to develop varieties that meet local preferences for colour.

\section{REFERENCES}

Abdelmula A., Von Kittlitz E and Stelling D. (1999). Heterosis and inheritance of drought tolerance in Faba bean (Vicia faba L.) Plant Breeding 118: 485-490.

Bänziger M. Bolaños. J. and Edmeades G. O. (1997). Increasing the drought tolerance in tropical maize from research on plant-water relations to impacts in farmers' fields.Pioneer HiBred Int, USA

Blade, S. F., Shetty, S. V. R., Terao, T., and Singh, B. B., (1997). Recent development in cowpea cropping systems research. pg 114-128. In: B. B. Singh, D. R. Mohan Raj, K. E. Dashiell, L. E. N. Jackai (eds). Advances in cowpea research. Co-publication of International Institute of Tropical Agriculture (IITA) and Japan International Research Centre for Agricultural Science (JIRCAS). IITA, Ibadan, Nigeria.

Blum, A. (1983). Genetic and physiological Relationship in plant breeding for drought resistance. Agric Water manage 7:195-205.

Dingkuhn, M., Singh, B. Clerget, J. Chantereau, and B. Sultan. (2006). Past, present and future criteria to breed crops for water-limited environments in West Africa. Agricultural Water Management 80:241-261.

Fery, R. L., and Singh B. B., (1997). Cowpea genetics: a review of recent literature. pg 13-29. In: Advances in cowpea research. B. B. Singh, D. R. Mohan Raj, K. E. Dashiell, L. E. N. Jackai International Research Centre for Agricultural Sciences (JIRCAS). IITA, Ibadan, Nigeria.

Fussell L K, Bidinger F. R. Bieler P (1991) Crop physiology and breeding for drought tolerance: research and development. Field Crops Res 27:183-199.

Gardner CO and Eberhart SA (1966) Analysis and interpretation of the variety cross diallel and related populations. Biometrics 22: 439-4452

Griffing B (1956) Concept of general and specific combining ability in relation to diallel crossing system. Aust $J$ Biol Sci 9: 463-493

Hall, A. E., Singh, B. B., and Ehlers, J. D. (1997). Cowpea breeding. Plant breeding Reviews 15:215-275.

Jatasra, D. S. (1980). Combining ability for grain weight in cowpea. Indian Journal of Genetics and Plant Breeding 40:330-333.

Langyintuo, A.S., J. Lowenberg-Deboer, D. Faye, D. Lambert, G. Ibro, B. Moussa, A. Kergna, S. Kushwaha, S. Musa, and G. Ntoukam. (2003). Cowpea supply and demand in West and Central Africa. Field Crops Res. 82:215-231.

Mai-Kodomi, Y., Singh B. B. Myers O. Yopp J. H. Gibson P. J. and Terao T. (1999). Two mechanisms of drought tolerance in cowpea. Indian Journal of Genetics 59:309 316.

Muchero W, Elhelers JD, Roberts PA (2008). Seedling stage drought-induced phenotypes and drought-responsive genes in diverse cowpea genotypes. Crop Science 48:541-552.

Padi, F. K. (2004). Relationship between stress tolerance and grain yield stability in cowpea. Journal of Agricultural Science, Cambridge 142:143-443.

Padi, F. K. (2007). Genotype $\times$ environment interaction and yield stability in a cowpea-based cropping system. Euphytica 158: 11 - 25.

Padi, F. K., Ehlers J.D. (2008). Effectiveness of early generation selection in cowpea for grain yield and agronomic characteristics in semi arid West Africa. Crop Science 48: $533-540$.

Padi, F.K. 2008. Response to selection for grain yield in cowpea and correlated response for earliness and grain size based on early generation selection. Annals of Applied Biology 152: 361 - 368 SARI (1996). Legumes improvements Programme. pg 46-60. Savannah Agricultural Research Institute Annual Report (1996) Tamale, Ghana. SARI (1997), Legumes improvements Programme. pg 111-118. Savannah Agricultural Research Institute Annual Report (1997) Tamale, Ghana. SARI (2007), Legumes improvements Programme. pg 94-99. Savannah Agricultural Research Institute, Annual Report (2007) Tamale, Ghana.

Shakel, K. A., and Hall, A. E. (1983). Comparison of water relation and osmotic adjustment in sorghum and cowpea under field condition. Australian Journal of plant Physiology 10:423-435.

Singh, S. R., and Jackai, L. E. N., (1985). Insect pests of cowpea in West Africa: their life cycle, economic importance and potentials for control. Pages 217-231 In: B. B. Singh, D. R., Mohan Raj, K. E. Dashiell, L. E. N. Jackai (eds) Advances in Cowpea Research. Copublication of International Institute of Tropical Agriculture (IITA) and Japan International Research Centre for Agricultural Science (JIRCARS). IITA, Ibadan, Nigeria.

Watanabe N, Naruse J, Austin RB, Morgan CL (1998) Variation in thylakoid proteins and photosynthesis in Syrian landraces of barley. Euphytica 82, 213-220. doi: 10.1007/BF00029563

Watanabe, L., Hakoyama, S., Terao, T., and Singh, B.B. (1997). Evaluation method for drought tolerance of cowpea. pg 141-146. In: BB Singh, Mohan Raj, K. Dashiell and K. E. N. Jackai (eds). Advances in cowpea Research Complication of International institute of Tropical Agricultures (IITA) and Japan International Research Centre for Agriculture Science Research centre for Agriculture Science (JIRCAS). IITA, Ibadan, Nigeria. 